\title{
RIWAYAT PEMBERIAN SUSU FORMULA DENGAN INDEK def-t PADA ANAK USIA DINI DI TK PERTIWI IV PONDOK LABU TAHUN 2020
}

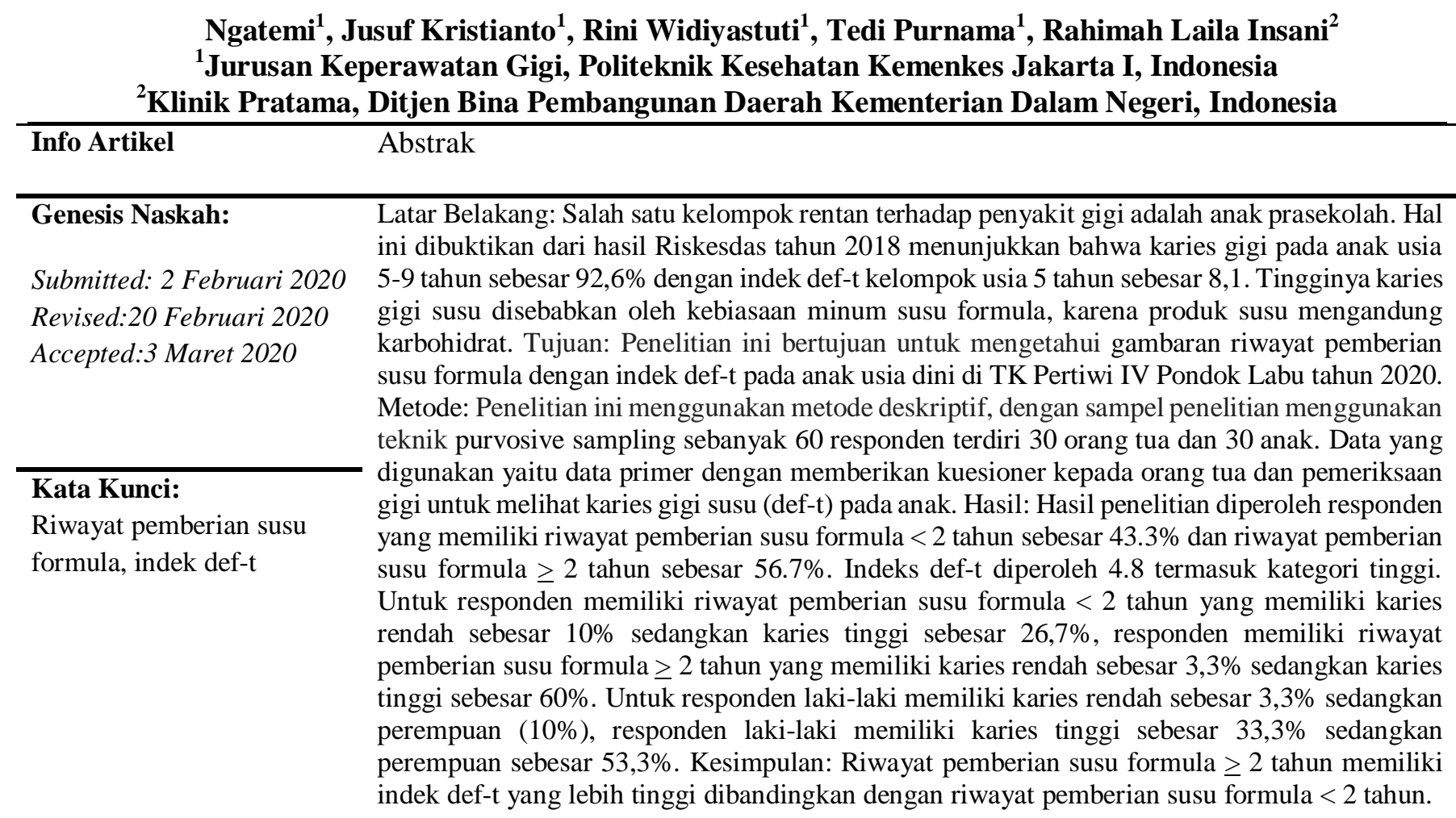

\section{HISTORY OF FORMULA MILK WITH def-t INDEX IN EARLY CHILDHOOD IN KINDERGARTEN PERTIWI IV PONDOK LABU 2020}

\begin{tabular}{|c|c|}
\hline Keywords: & Abstract \\
\hline $\begin{array}{l}\text { History of Formula Milk, } \\
\text { def-t index }\end{array}$ & 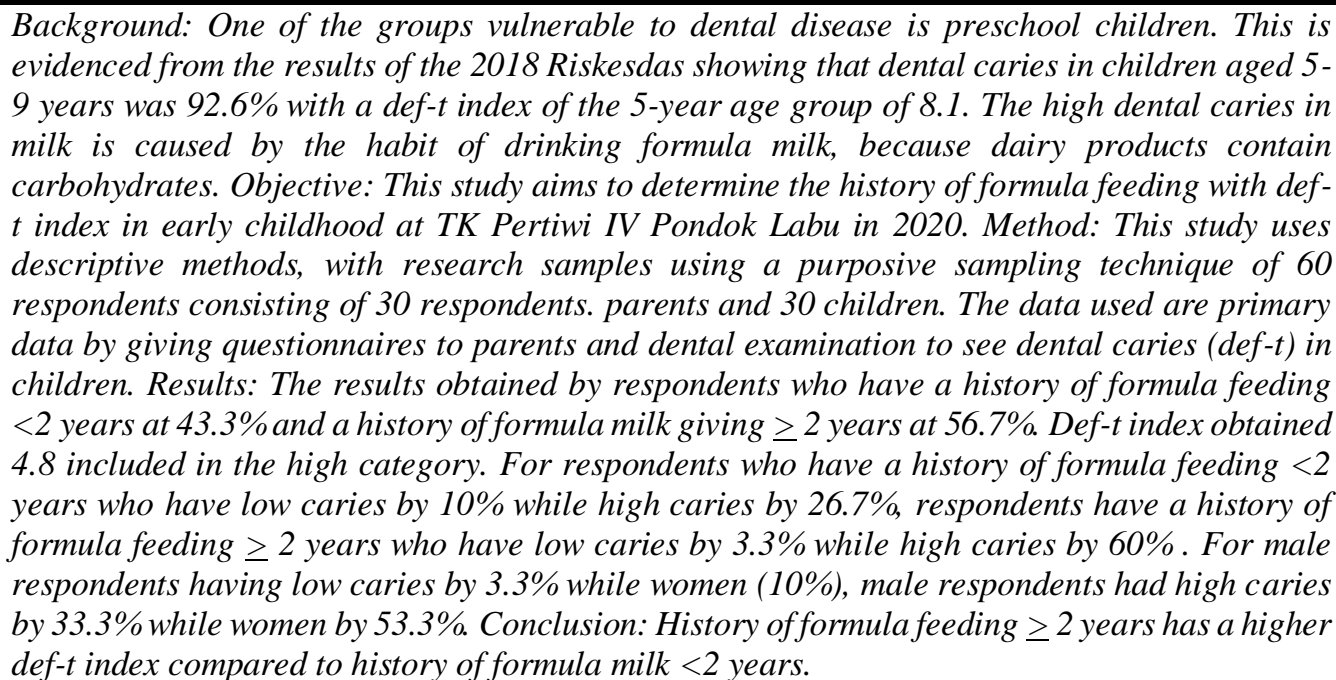 \\
\hline
\end{tabular}

Korespondensi Penulis:

Tedi Purnama

Jl. Wijaya Kusuma No. 47-48 Cilandak Jakarta Selatan

email: tedypurnama23@yahoo.com 


\section{Pendahuluan}

Kesehatan gigi dan mulut merupakan bagian integral dari kesehatan umum yang dapat mendukung percepatan pencapaian MDGs yaitu meningkatkan kesehatan anak balita. Untuk mencapai kesehatan gigi dan mulut yang optimal pada balita, maka harus dilakukan perawatan secara berkala. Perawatan dapat dimulai dengan memperhatikan konsumsi makanan, pembersihan plak dan sisa makanan yang tersisa dengan menyikat gigi secara teratur dan benar. Dengan memperhakan hal-hal tersebut, maka akan dicapai suatu kesehatan gigi dan mulut yang optimal yang akan meningkatkan kesehatan tubuh secara keseluruhan (Kemenkes RI, 2012).

Kelompok rentan terhadap karies gigi diantranya; prasekolah, anak sekolah ibu hamil dan lansia (Kemenkes RI, 2012). Hal ini dibuktikan dari hasil Riskesdas tahun 2018 menunjukkan bahwa karies gigi pada anak usia 5-9 tahun sebesar 92,6\% dengan indek def-t kelompok usia 5 tahun sebesar 8,1 (Kemenkes RI, 2018).

Karies adalah suatu penyakit infeksi yang dihasilkan dari interaksi bakteri. Karies gigi terjadi karena proses demineralisasi dari interaksi bakteri pada permukaan gigi. Bakteri bersifat asam sehingga dalam periode waktu tertentu, asam akan merusak email gigi dan menyebabkan gigi menjadi berlubang. Faktor etiologi terjadinya karies yaitu mikroorganisme plak, diet dan waktu. Karies pada gigi sulung sering menyerang gigi molar rahang bawah, gigi molar rahang atas, dan gigi anterior rahang atas. Pada masa periode gigi bercampur karies gigi sering menyerang pada gigi molar permanen rahang bawah dibandingkan dengan gigi rahang atas (Mustika dkk, 2014). Hal ini terjadi sangat cepat dan mengenai beberapa gigi serta sering menimbulkan rasa sakit, kesulitan makan dan gangguan berbicara. Jika tidak dirawat dapat memicu terjadinya kesulitan mengunyah karena sakit gigi atau kehilangan dini pada gigi sulung (Winda dkk, 2015). Karies gigi pada masa kanak-kanak dapat mengganggu sistem pengunyahan dan mengganggu sistem pencernaan (Dogar cit. Ngatemi, 2020). Menurut Purnama dkk (2019) menyatakan karies gigi anak dapat memengaruhi kualitas hidup bahkan pertumbuhan dan perkembangan gigi anak.
Hasil penelitian Jayanti (2012) kejadian karies pada anak TK Aisyiyah menunjukkan rata-rata terdapat kejadian karies pada anak, yaitu sebanyak 41 responden $(69 \%)$ dan sisanya 18 responden $(31 \%)$ tidak terdapat kejadian karies pada gigi siswanya. Penelitian Rengkuan dkk (2017) di TK Kartika Manado juga menunjukan status karies gigi pada sebagian besar mengalami decay (78\%), missing sebesar (22\%) dan tidak ada subyek yang melakukan filling. Hal tersebut termasuk dalam kategori tinggi bila dbandingkan dengan target WHO tahun 2018 yaitu $50 \%$ anak prasekolah bebas dari karies.

Tingginya karies gigi susu disebabkan oleh kebiasaan minum susu formula, karena produk susu mengandung karbohidrat (Ghaitsa dkk, 2017). Menurut Sulistyoningsih dalam Purwaningsih (2016) menyatakan bahwa susu formula merupakan suatu produk makanan yang mengandung nilai gizi cukup tinggi, karena sebagian besar zat gizi esensial seperti protein, kalsium, fosfor, vitamin A, dan vitamin B1 ada di dalam susu formula. Tambahan susu formula dalam pola konsumsi anak sangat dianjurkan untuk melengkapi kebutuhan zat gizi dan nutrisi anak bagi pertumbuhan dan perkembangan. Namun terkadang pemberian susu formula ini malahan menimbulkan masalah bagi kesehatan anak, salah satunya berkaitan dengan kesehatan gigi dan mulut anak. Pola konsumsi susu formula yang kurang tepat seperti cara penyajian yang menggunakan botol yang dihubungkan dengan lama pemberian, frekuensi, dan waktu pemberian dapat menyebabkan terjadinya karies pada anak (Purwaningsih, 2016).

Hasil studi pendahuluan pada saat praktik Pelayanan Asuhan Kesehatan Gigi dan Mulut Masyarakat di TK Pertiwi IV Pondok Labu dengan melakukan wawancara 10 responden orang tua menyatakan bahwa 7 dari 10 anak menggunakan susu formula dan hasil pemeriksaan pada siswa-siswi TK Pertiwi banyak yang mengalami karies gigi.

Berdasarkan uraian diatas, peneliti tertarik untuk untuk mengetahui gambaran riwayat pemberian susu dan def-t pada anak usia dini di TK Pertiwi IV Pondok Labu tahun 2020 


\section{Metode}

Jenis penelitian ini menggunakan metode penelitian deskriptif yaitu melihat gambaran riwayat pemberian susu dan def-t pada anak usia dini di TK Pertiwi IV Pondok Labu tahun 2020. Populasi pada penelitian ini adalah seluruh murid dan orang tua di TK Pertiwi IV Pondok Labu tahun 2020. Teknik pengambilan sampel menggunakan purvosive sampling yaitu pengambilan sampel yang didasarkan pada suatu pertimbangan tertentu yang dibuat oleh peneliti sendiri. Sampel penelitian ini sebanyak 60 orang yang terdiri dari 30 orang tua dan 30 anak. Data yang digunakan adalah data primer yaitu riwayat pemberian susu formula dengan mengisi kuesioner dan indek def-t dengan melakukan pemeriksaan secara langsung pada sampel yang dimaksud. Penelitian ini diolah dan dianalisa dalam program excel dan disajikan dalam bentuk distribusi frekuensi.

\section{Hasil}

Hasil pengumpulan data tentang gambaran riwayat pemberian susu formula pada anak usia dini di TK Pertiwi IV Pondok Labu tahun 2020 terdapat pada tabel berikut:

Tabel 1. Distribusi frekuensi riwayat pemberian susu formula pada anak usia dini di TK Pertiwi IV Pondok Labu

\begin{tabular}{ccc}
\hline $\begin{array}{c}\text { Riwayat Pemberian } \\
\text { Susu Formula }\end{array}$ & Jumlah & $\begin{array}{c}\text { Persentasi } \\
(\mathbf{\%})\end{array}$ \\
\hline Waktu $<2$ tahun & 13 & 43.3 \\
Waktu $\geq 2$ tahun & 17 & 56.7 \\
\hline Jumlah & 30 & 100 \\
\hline
\end{tabular}

Tabel 1 menunjukan bahwa responden yang memiliki riwayat pemberian susu formula $<2$ tahun sebanyak 13 murid (43.3\%) dan riwayat pemberian susu formula $\geq 2$ tahun sebanyak 17 murid (56.7\%). Kemudian indek def-t pada anak usia dini di TK Pertiwi IV Pondok Labu tahun 2020 terdapat pada tabel berikut:

Tabel 2. Gambaran Rata-rata def-t pada Anak Usia Dini di TK Pertiwi IV Pondok Labu

\begin{tabular}{|c|c|c|}
\hline $\begin{array}{c}\text { Jumlah } \\
\text { Responden }\end{array}$ & $\begin{array}{c}\text { Jumlah } \\
\text { def-t }\end{array}$ & Rata-rata \\
\hline 30 & 144 & 4.8 \\
\hline
\end{tabular}

(c) Jurusan Keperawatan Gigi Poltekkes Kemenkes Jakarta I Jl. Wijaya Kusuma No. 47-48 Cilandak Jakarta Selatan, Indonesia email: jdht@poltekkesjakarta1.ac.id
Tabel 2 menunjukkan dari 30 responden didapatkan jumlah def-t sebanyak 144 dan def-t ratarata sebesar 4.8. Hal ini dapat diartikan bahwa setiap murid yang diperiksa memiliki pengalaman karies gigi susu sebanyak 4 - 5 gigi tiap siswa. Kemudian peneliti mengelompokkan indeks def-t menurut standar WHO tahun 2018 yaitu dapat dilihat pada tabel berikut:

Tabel 3. Distribusi frekuensi indek def-t pada anak usia dini di TK Pertiwi IV Pondok Labu

\begin{tabular}{ccc}
\hline Indek def-t & Jumlah & Persentasi (\%) \\
\hline Rendah & 4 & 13.3 \\
Tinggi & 26 & 86.7 \\
\hline Jumlah & 30 & 100 \\
\hline
\end{tabular}

Tabel 3 menunjukkan bahwa responden yang mempunyai def-t kriteria rendah sebanyak 4 murid (13.3\%) dan kriteria tinggi sebanyak 26 murid (86.7\%). Kemudian riwayat pemeberian susu formula dengan def-t pada anak usia dini di TK Pertiwi IV Pondok Labu tahun 2020 terdapat pada tabel berikut:

Tabel 4. Gambaran riwatat pemberian susu Formula dengan indek def- t pada anak usia dini di TK Pertiwi IV Pondok Labu

\begin{tabular}{ccccc}
\hline \multirow{2}{*}{ Indek def-t } & \multicolumn{3}{c}{ Riwayat Pemberian Susu Formula } \\
\cline { 2 - 5 } & \multicolumn{2}{c}{$<2$ tahun } & \multicolumn{2}{c}{$\geq 2$ tahun } \\
\cline { 2 - 5 } & $\mathrm{f}$ & $\%$ & $\mathrm{f}$ & $\%$ \\
\hline Rendah & 3 & 10 & 1 & 3,3 \\
Tinggi & 8 & 6,7 & 18 & 60 \\
\hline Jumlah & 11 & 6,6 & 19 & 63,3 \\
\hline
\end{tabular}

Tabel 4. menunjukan bahwa responden memiliki riwayat pemberian susu formula $<2$ tahun yang memiliki karies rendah sebanyak 3 murid (10\%) sedangkan riwayat pemberian susu formula $<2$ tahun yang memiliki karies tinggi sebanyak 8 murid (26,7\%). Responden memiliki riwayat pemberian susu formula $\geq 2$ tahun yang memiliki karies rendah sebanyak 1 murid (3,3\%) sedangkan riwayat pemberian susu formula $\geq 2$ tahun yang memiliki karies tinggi sebanyak 1 murid (60\%). 
Tabel 5. Gambaran indeks def- $t$ pada anak usia dini di TK Pertiwi IV Pondok Labu berdasarkan jenis kelamin

\begin{tabular}{ccccc}
\hline \multirow{2}{*}{ Indeks def-t } & \multicolumn{4}{c}{ Jenis Kelamin } \\
\cline { 2 - 5 } & \multicolumn{2}{c}{ Laki-laki } & \multicolumn{3}{c}{ Perempuan } \\
\cline { 2 - 5 } & $\mathrm{f}$ & $\%$ & $\mathrm{f}$ & $\%$ \\
\hline Rendah & 1 & 3,3 & 3 & 10 \\
Tinggi & 10 & 33,3 & 16 & 53,3 \\
\hline Jumlah & 11 & 36,6 & 19 & 63,3 \\
\hline
\end{tabular}

Tabel 5 menunjukan bahwa responden laki-laki yang memiliki karies rendah sebanyak 1 murid $(3,3 \%)$ dan responden perempuan yang memiliki karies rendah sebanyak 3 murid (10\%). Responden laki-laki yang memiliki karies tinggi sebanyak 10 murid $(33,3 \%)$ dan responden perempuan yang memiliki karies tinggi sebanyak 16 murid $(53,3 \%)$.

\section{Pembahasan}

Penelitian ini bertujuan untuk mendapatkan gambaran riwayat pemberian susu formula dengan indek def-t pada anak usia dini di TK Pertiwi IV Pondok Labu tahun 2020. Hasil pengumpulan data didapatkan data responden laki-laki sebanyak 11 murid (36.7\%) dan perempuan 19 murid (63.3\%).

Hasil penelitian gambaran riwayat pemberian susu formula didapatkan sebagian besar responden yang memiliki riwayat pemberian susu formula $\geq 2$ tahun sebanyak 17 murid (56.7\%). Hasil penelitian ini bila dibandingkan dengan penelitian Jingga dkk (2019) pada TK Islam Pangeran Diponegoro menunjukkan bahwa jumlah anak yang mengkonsumsi susu formula selama 2-3 tahun memiliki jumlah terbanyak yaitu 34 anak $(51,6 \%)$. Maka dibisa diartikan baik hasil penelitian terdahulu dan hasil penelitian yang dilakukan peneliti samasama memiliki riwayat pemberian susu formula $\geq 2$ tahun. Tingginnya pemberian susu formula dimungkinkan karena pengetahuan orang tua dan kesibukan orang tua berkerja diluar rumah. Hal ini didukung Mahardika (2014) menyatakan salah satu faktor yang sangat mempengaruhi orang tua dalam pemberian susu formula adalah pengetahuan ibu dan ibu yang bekerja diluar rumah.

(C) Jurusan Keperawatan Gigi Poltekkes Kemenkes Jakarta I Jl. Wijaya Kusuma No. 47-48 Cilandak Jakarta Selatan, Indonesia email: jdht@poltekkesjakarta1.ac.id
Hasil penelitian gambaran indek def-t didapatkan dari 30 responden didapatkan jumlah def-t sebesar 144 dan def-t rata-rata sebesar 4.8, dengan sebagain besar responden yang mempunyai indek def-t kriteria tinggi sebanyak 26 murid (86.7\%). Hasil tersebut dapat termasuk tinggi karena ini masih jauh dibandingkan dengan target nasional jangka panjang tahun 2018 dibidang kesehatan gigi dan mulut dimana target def- $\mathrm{t}$ sebesar 1. Hasil penelitian ini juga tidak jauh berbeda bila dibandingkan dengan penelitian Winda $\mathrm{dkk}$ (2015) pada anak PAUD di Desa Pineleng II Indah menunjukkan bahwa siswa yang memiliki karies sebanyak $76,56 \%$ dan yang tidak ada karies $23,44 \%$ dengan indeks def-t sebesar 4,3. Hasil penelitian tersebut bisa diartikan bahwa penelitian terdahulu dan hasil penelitian yang dilakukan peneliti sama-sama memiliki karies gigi susu dengan kriteria tinggi. Hal ini sebabkan karena anak TK Pertiwi IV pondok labu memiliki riwayat pemberian susu formula, terlihat dari hasil penelitian menunjukkan anak memiliki riwayat pemberian susu formula $\geq 2$ tahun sebesar $56.7 \%$. Didukung pendapat Ghaitsa dkk (2017) menyatakan kebiasaan minum susu formula dapat menyebabkan tingginya karies gigi susu karena produk susu mengandung karbohidrat dan pendapat Purwaningsih (2016) menyatakan pemberian susu formula ini dapat menimbulkan masalah bagi kesehatan anak, salah satunya berkaitan dengan kesehatan gigi dan mulut anak. Pola konsumsi susu formula yang kurang dapat menyebabkan terjadinya karies pada anak. Diperkuat juga hasil Penelitian Sari (2017) di TK Dayyinah Kids Pekanbaru menunjukkan bahwa dari 114 responden didapatkan anak yang diberikan susu formula yang mengalami karies gigi mayoritas sebanyak 60 orang $(52,6 \%)$.

Hasil penelitian gambaran riwayat pemberian susu formula dengan indek def-t menunjukkan riwayat pemberian susu formula $\geq 2$ tahun memiliki karies tinggi lebih banyak dibandingkan riwayat pemberian susu formula $<2$ tahun. Maka bisa diartikan riwayat pemberian susu formula $\geq 2$ tahun memiliki resiko terjadinya karies gigi pada anak usia dini. Hal ini sejalan dengan penelitian Jingga dkk (2019) membuktikan bahwa riwayat konsumsi susu formula merupakan factor risiko karies gigi pada siswa taman kanak-kanak dengan nilai OR 7,718 artinya anak 
dengan konsumsi susu formula selama $\geq 2$ tahun memiliki 7,718 kali lipat untuk terkena karies gigi dibandingkan anak yang mengkonsumsi susu formula $<2$ tahun.

Hasil penelitian gambaran indek def-t berdasarkan jenis kelamin menunjukan bahwa anak perempuan memiliki karies gigi lebih banyak dibandingkan anak laki-laki. dan responden dengan jenis kelamin perempuan yang karies sebanyak $(37,2 \%)$. Hal ini dikarenakan gigi pada perempuan lebih cepat erupsi daripada laki-laki. Cepatnya erupsi gigi pada perempuan menyebabkan lebih rentan terhadap risiko karies gigi. Diperkuat hasil penelitian Dewi dkk (2017) membukitkan bahwa status karies gigi pada pasien perempuan lebih tinggi dibandingkan dengan pasien laki-laki.

\section{Kesimpulan dan Saran}

Berdasarkan hasil penelitian, dapat disimpulkan bahwa:

1. Didapatkan sebagian besar murid TK Pertiwi IV Pondok Labu memiliki riwayat pemberian susu formula $\geq 2$ tahun sebanyak 16 siswa memiliki kriteria $(53,3 \%)$

2. Didapatkan indek def-t rata-rata pada anak usia dini TK Pertiwi IV Pondok Labu sebesar 4.8 termasuk kategori tinggi

3. Didapatkan gambaran riwayat pemberian susu formula $\geq 2$ tahun memiliki indek def-t lebih tinggi dibandingkan riwayat pemberian susu formula $<2$ tahun

4. Didapatkan indek def-t pada anak perempuan lebih tinggi dibandingkan anak laki-laki

Sehubungan dengan hasil penelitian masih menunjukkan tingginya karies gigi susu diakibatkan pemberian susu formula maka dapat disarankan sebagai berikut:

1. Bagi orang tua diharapkan untuk mengurangi pemberian susu formula pada anaknya dan membimbing menggosok gigi anaknya secara teratur minimal setelah sarapan dan sebelum tidur malam, serta anak yang memiliki karies gigi sebaiknya segera dilakukan upaya kuratif dengan penambalan gigi agar mengembalikan fungsi gigi
2. Bagi Lembaga Pendidikan Usia Dini diharapkan dapat bekerja sama dengan Puskesmas atau fasilitas pelayanan kesehatan gigi agar dapat diadakan penyuluhan kesehatan gigi sehingga murid memiliki pengetahuan yang lebih baik lagi mengenai kesehatan gigi.

3. Bagi Puskesmas perlu diupayakan untuk mengikutsertakan TK/PAUD dalam program UKGS agar dapat dilakukan upaya pencegahan sedini mungkin.

\section{Daftar Pustaka}

Dewi OR, Herwanda., Novita FC (2017). Gambaran Status Karies Gigi (Indeks DMF-T) pada Pasien Thalasemia Beta Mayor di Rumah Sakit Umum Daerah Dr. Zainoel Abidin Banda Aceh. Journal Caninus Denstistry: Volume 2, Nomor 2 (Mei 2017): $71-77$

Ghaitsa, Widodo, Rosihan, Adhani (2017). Perbandingan Indeks Karies Antara Anak Yang Mengkonsumsi Susu Botol Dengan Tanpa Botol Usia 2-5 Tahun. Dentino (Jur. Ked. Gigi): Vol II. No 2. September $2017: 205-210$

Jayanti DC (2012). Hubungan Tingkat Pengetahuan Ibu Tentang Karies Gigi Dengan Kejadian Karies Gigi Pada Anak Tk Aisyiyah Kateguhanan Sawit Boyolali. Naskah Publikasi. Fakultas Ilmu Kesehatan Universitas Muhammadiyah Surakarta

Jingga E, Setyawan H, Yuliawati S (2019). Hubungan Pola Pemberian Susu Formula Dengan Kejadian Early Childhood Caries (ECC) Pada Anak Prasekolah Di TK Islam Diponegoro Kota Semarang. Jurnal Kesehatan Masyarakat (eJournal): Volume 7, Nomor 1, Januari 2019

Kementerian Kesehatan Republik Indonesia (2012). Pedoman Pemeliharaan Kesehatan Gigi Dan Mulut Ibu Hamil Dan Anak Usia Balita Bagi Tenaga Kesehatan Di Fasilitas Pelayanan Kesehatan. Direktorat Jenderal Bina Upaya Kesehatan, Jakarta.

Kementerian Kesehatan Republik Indonesia (2018). Riset Kesehatan Dasar. Badan Penelitian dan Pengembangan, Jakarta.

Mustika MD, Amy NC, Cholil (2014). Insidensi Karies Gigi Pada Anak Usia Prasekolah Di Tk Merah Mandiangin Martapura Periode 2012-2013. Dentino Jurnal Kedokteran Gigi: Vol II. No 2. September 2014 
Ngatemi, Purnama T. (2020). Dental Health Handbook as Parents Monitoring in the Formation of Independence for Brushing Teeth in Early Childhood. Indian Journal of Public Health Research Development, 11(1):785-790

Purnama T, Rasipin R, Santoso B. (2019). Pengaruh Pelatihan Tedi's Behavior Change Model pada Guru dan Orang Tua terhadap Keterampilan Menggosok Gigi Anak Prasekolah. Jurnal Quality Kesehatan. 13(2):75-81.

Purwaningish A (2016). Pengaruh Pemberian Susu Formula Menggunakan Botol Susu (Dot) Terhadap Kejadian Rampan Karies Pada Anak Prasekolah Di Kelurahan Pabelan. Naskah Publikasi. Fakultas Ilmu Kesehatan Universitas Muhammadiyah Surakarta
Rengkuan Y. ER, Pemsi MW, Christy NM (2017). Gambaran status karies dan status gizi pada murid TK Kartika XX-16 Manado. Jurnal e-GiGi $(e G)$ : Volume 5 Nomor 2, Juli-Desember 2017

Sari PE (2017) Hubungan Pemberian Susu Formula Dengan Karies Gigi Pada Anak Pra Sekolah Di Tk Dayyinah Kids. Naskah Publikasi. Akademi Kebidanan Dharma Husada Pekanbaru

Winda US, Paulina G, Dinar AW (2015). Gambaran Karies Rampan Pada Siswa Pendidikan Anak Usia Dini Di Desa Pineleng II Indah. Jurnal e-GiGi $(e G)$ : Volume 3, Nomor 1, Januari-Juni 2015 